\title{
Is suvorexant a better choice than alternative hypnotics?
}

\section{[version 1; peer review: 2 approved]}

\author{
Daniel F. Kripke (iD) \\ Scripps Clinic Viterbi Family Sleep Center, La Jolla, CA, USA
}

V1 First published: 03 Aug 2015, 4:456
https://doi.org/10.12688/f1000research.6845.1
Latest published: 03 Aug 2015, 4:456

https://doi.org/10.12688/f1000research.6845.1

\section{Abstract}

Suvorexant is a novel dual orexin receptor antagonist (DORA) newly introduced in the U.S. as a hypnotic, but no claim of superiority over other hypnotics has been offered. The manufacturer argued that the 5 and $10 \mathrm{mg}$ starting doses recommended by the FDA might be ineffective. The manufacturer's main Phase III trials had not even included the $10 \mathrm{mg}$ dosage, and the $5 \mathrm{mg}$ dosage had not been tested at all in registered clinical trials at the time of approval. Popular alternative hypnotics may be similarly ineffective, since the FDA has also reduced the recommended doses for zolpidem and eszopiclone. The "not to exceed" suvorexant dosage of $20 \mathrm{mg}$ does slightly increase sleep. Because of slow absorption, suvorexant has little effect on latency to sleep onset but some small effect in suppressing wakening after sleep onset and in improving sleep efficiency. The FDA would not approve the manufacturer's preferred $40 \mathrm{mg}$ suvorexant dosage, because of concern with daytime somnolence, driving impairment, and possible narcolepsy-like symptoms. In its immediate benefits-to-risks ratio, suvorexant is unlikely to prove superior to currently available hypnotics-possibly worse-so there is little reason to prefer over the alternatives this likely more expensive hypnotic lesstested in practice. Associations are being increasingly documented relating hypnotic usage with incident cancer, with dementia risks, and with premature death. There is some basis to speculate that suvorexant might be safer than alternative hypnotics in terms of cancer, dementia, infections, and mortality. These safety considerations will remain unproven speculations unless adequate long-term trials can be done that demonstrate suvorexant advantages.

\section{Keywords}

suvorexant, Belsomra ${ }^{\circledR}$, zolpidem, eszopiclone , melatonin , sleep , hypnotic, mortality , cancer

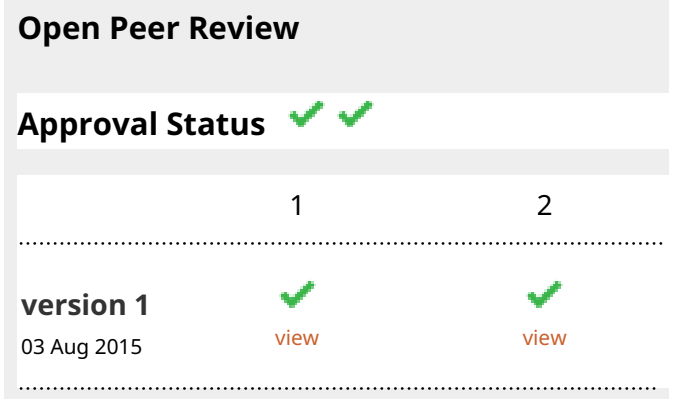

1. Jerome M. Siegel, University of California, Los Angeles, Los Angeles, USA

2. Børge Sivertsen, Norwegian Institute of Public Health, Bergen, Norway Any reports and responses or comments on the article can be found at the end of the article. 
Corresponding author: Daniel F. Kripke (DanKripke@gmail.com)

Competing interests: Since 1979 publication of hypnotics epidemiology from the American Cancer Society CPSI study, the author has been a frequent critic of hypnotics risks and benefits, especially through his non-profit internet web site,

www.DarkSideOfSleeping Pills.com, that provides readers with more extensive information and references about risks of hypnotics. Dr. Kripke's family owns stock and options in a large conglomerate that in turn invested a tiny percentage of its capital in Sanofi-Aventis stock. The author has no relevant affiliations or financial involvement with any organization or entity with a financial interest in or financial conflict with the subject matter or materials discussed in the manuscript. This includes employment, consultancies, honoraria, other stock ownership or options, expert testimony, grants or patents received or pending or royalties. No writing assistance was utilized in the production of this manuscript.

Grant information: The author(s) declared that no grants were involved in supporting this work.

Copyright: ( 2015 Kripke DF. This is an open access article distributed under the terms of the Creative Commons Attribution License, which permits unrestricted use, distribution, and reproduction in any medium, provided the original work is properly cited.

How to cite this article: Kripke DF. Is suvorexant a better choice than alternative hypnotics? [version 1; peer review: 2 approved] F1000Research 2015, 4:456 https://doi.org/10.12688/f1000research.6845.1

First published: 03 Aug 2015, 4:456 https://doi.org/10.12688/f1000research.6845.1 


\section{A new kind of hypnotic drug}

The manufacturer has begun U.S. marketing for suvorexant (Belsomra $\left.{ }^{\circledR}\right)$, a dual orexin receptor antagonist (DORA) offered as a new hypnotic for treatment of insomnia (See Table 1 for abbreviations). The manufacturer's information emphasizes that the drug is novel and acts by a mechanism distinct from the benzodiazepine agonists and antihistamines commonly marketed as hypnotics. The prescribing information does not claim that suvorexant has greater benefits or fewer risks than other drugs marketed for insomnia. Indeed, a search of PubMed (www.PubMed.gov), ClinicalTrials.gov (www. ClinicalTrials.gov), and the International Clinical Trials Registry Platform multinational clinical trials registries (http://www.who. int/ictrp/) found no trials comparing suvorexant with other hypnotics for treatment of insomnia (searched July 17, 2015). Some small comparative trials have been done focused on specific adverse risks such as middle-of-the night impairment and driving impairment ${ }^{1}$. Physicians and their patients may thus wonder whether they should switch from familiar hypnotics to suvorexant that may have higher costs than popular generics. This discussion presents a clinician's opinions about the choice of hypnotics. Not discussed here are the much more complex issues of when insomnia should be treated with hypnotics and when new developments such as the cognitivebehavioral treatment of insomnia or bright light treatment should be seen as better choices than any hypnotic.

Orexins are excitatory neurotransmitters, secreted primarily by a small number of cells in the lateral hypothalamus ${ }^{2-4}$. Orexins have many actions in the brain ${ }^{2,4,5}$, but the current interest is in orexin actions in maintaining wakefulness, for example, through activating tuberomammillary histamine neurons that secrete wakemaintaining histamine throughout many brain areas ${ }^{6,7}$. Suvorexant blocks orexin's stimulation of histaminergic neurons. Suvorexant advocates suggests that there is a qualitative difference between suvorexant antagonizing wakefulness whereas in contrast, competitive hypnotics promote sleep, but I cannot conceptualize this distinction clearly. For example, benzodiazepine receptor agonists and histamine receptor antagonists (antihistamines) also suppress histaminergic alerting, besides diverse other actions ${ }^{8}$. Sleep-wake regulation has been conceptualized as a "flip-flop switch" in which a stronger flip or a weaker flop might produce equivalent switching.

When orexin-secreting neurons or orexin receptors are destroyed by autoimmune reactions, narcolepsy may result ${ }^{10-13}$. Narcolepsy is an illness characterized by sleep attacks and daytime somnolence, as well as cataplexy (sudden transient weakness or paralysis), sleep paralysis, and hallucinations. The suvorexant inspiration is to help insomnia patients to sleep better by reducing orexigenic maintenance of wakefulness, perhaps similar to what occurs among narcoleptics ${ }^{14,15}$, but this idea has limitations. A characteristic of narcolepsy is disturbed nocturnal sleep ${ }^{16,17}$. Also, many insomnia patients arise out of bed during the night, and if treated with an orexin receptor antagonist, they might experience certain peculiar narcoleptic symptoms--more about this later. Narcoleptics may not experience more total 24-hour sleep than unaffected people, but more of their sleepiness and sleep tend to occur during the day ${ }^{16,17}$. Indeed, narcoleptics suffer daytime somnolence as characterized by a daytime "multiple sleep latency test." Accordingly, narcolepsy is not usually characterized by a daytime feeling of being wellrested. Because of the relatively long half-life of suvorexant and its day-by-day accumulation, suvorexant might sometimes produce effects like narcolepsy symptoms during the day as well as at night.

Some physicians advise against trying new drugs without proven advantages, until several years of long-term Phase IV monitoring has allowed more experience with the benefits and adverse effects. Let us review some of what is currently known about suvorexant immediate benefits and risks, to offer matters worth considering in making clinical choices in comparison with alternative hypnotics. I shall also emphasize what is unknown, concluding with issues of long-term benefits and risks that may ultimately be far more important than the immediate benefit/risk ratio.

\begin{tabular}{|c|c|}
\hline ABBREVIATION & MEANING \\
\hline ADHD & Attention Deficit Hyperactivity Disorder \\
\hline $\mathrm{AHI}$ & Apnea-Hypopnea Index (respiratory disturbances per hour of sleep) \\
\hline BMI & Body Mass Index \\
\hline COPD & Chronic Obstructive Pulmonary Disease \\
\hline CYP2C19 & cytochrome P450 2C19, a liver enzyme acting on drug metabolism \\
\hline CYP3A & cytochrome P450, family 3 , subfamily A: a group of enzymes catalyzing drug metabolism \\
\hline DEA & United States Drug Enforcement Administration \\
\hline DORA & dual orexin receptor antagonist \\
\hline FDA & United States Food and Drug Administration \\
\hline GABA & Gamma-AminoButyric Acid \\
\hline Non-REM & sleep other than the REM sleep stage \\
\hline PSG & PolySomnoGram, generally a sleep recording including EEG \\
\hline REM & Rapid Eye Movement (sleep stage) \\
\hline $\mathrm{SpO}_{2}$ & pulse oximetric arterial saturation of blood, e.g., in percent saturation \\
\hline$T_{\max }$ & Time to Maximum drug concentration in blood \\
\hline URI & Upper Respiratory Infection \\
\hline WASO & Wake After Sleep Onset, e.g., mid-sleep awakenings or early awakening \\
\hline
\end{tabular}




\section{Immediate benefits of suvorexant and alternative hypnotics}

Since we do not have comparative controlled trials of suvorexant versus competing hypnotics given for insomnia, the best we can do is to review the evidence of suvorexant benefits versus placebo in randomized double-blind controlled trials. Then we can discuss whether these benefits are likely to be superior or equal to those of popular alternatives, even though randomized unbiased comparative trials are not available.

Many insomnia patients consume hypnotics at bedtime hoping to benefit by better function on the following day. In some studies, suvorexant on average made various kinds of objectively-measured performance such as word recall and driving worse the next morning ${ }^{1}$, but no significant areas of improved objective function were documented $^{1}$. If the primary hypnotic benefit desired is to improve next-day performance (measured objectively), suvorexant does not seem to offer that benefit. Quite the opposite. Note that many of the competitive popular hypnotics likewise make an insomnia patient's next-morning performance worse, not better ${ }^{18-20}$. It is conceivable that once a hypnotic is fully metabolized (often a variable number of hours after wake-up time), sedation would dissipate and objective performance might rebound. Moreover, considering that insomnia patients sometimes experience increased anxiety after taking a short-acting hypnotic ${ }^{21}$, and some hypnotics cause increased insomnia on the following night ${ }^{22}$, afternoon-evening rebound activation and accompanying performance enhancements might conceivably result from some short-acting hypnotics, but this enhancement has not been proven with statistical rigor $^{23}$ and certainly not with suvorexant. Indeed, I know of no objective evidence that any hypnotic (approved in the U.S.) taken at bedtime improves the next-day performance of insomnia patients. I emphasize objective performance because (like alcoholics), intoxicated hypnotic patients commonly subjectively assert that their performance is enhanced when objective testing shows that it is not.

Prolonged-release melatonin (Circadin $\left.{ }^{\circledR}\right)$, though not FDA-approved in the U.S., may be an exception to the general failure of sedativehypnotics to improve next-day performance. Manufacturersponsored studies have reported several kinds of performance enhancement ${ }^{24,25}$, and there are some reported sleep and behavioral improvements among children with ADHD given ordinary melatonin $^{26}$.

Sleep induction strengthens as the suvorexant dosage increases ${ }^{1,27}$. Although the manufacturer requested an initial suvorexant dosage ranging from $40 \mathrm{mg}$ down to $15 \mathrm{mg}$, the FDA would only allow a recommended dose of $10 \mathrm{mg}$ "not to exceed $20 \mathrm{mg}$ daily" 28 , concluding that a lowered dosage was necessary to reduce the excessive risks produced by higher dosages ${ }^{29}$. The company's scientists were quoted as telling an FDA committee that "ten milligrams is ineffective," from a patient's point of view ${ }^{4,14}$. My opinion that 10 $\mathrm{mg}$ is generally ineffective agrees with that expressed at that time by the manufacturer. However, desperate to sleep, insomnia patients often take more than the recommended starting dose. Among the first 21 User Reviews of suvorexant listed at the popular WebMD internet site (www.webmd.com), 2 reported satisfaction with the recommended $10 \mathrm{mg}$ starting dose, 13 reported taking more than
$10 \mathrm{mg}$ (as much as $40 \mathrm{mg}$, sometimes combined with other sedatives), and the others did not report their dosage information ${ }^{30}$. The FDA authorizes the nocturnal dosage to be increased to $20 \mathrm{mg}$ if $10 \mathrm{mg}$ proves well-tolerated but ineffective. It will be interesting to learn what dosages representative suvorexant patients actually choose to consume.

In the first night of polysomnographic data, $10 \mathrm{mg}$ suvorexant decreased the latency to persistent sleep $3.4 \mathrm{~min}$. (-15.6, 8.7, 95\% Confidence Interval) more than placebo, i.e., there was no statistically significant benefit ${ }^{1,27,31}$. Likewise, $20 \mathrm{mg}$ reduced the sleep latency by $9.4 \mathrm{~min} .(-21.5,2.9)$ more than placebo, also not statistically significant, and not clinically significant compared to an initial sleep latency of about 70 minutes. At the end of week 4, $10 \mathrm{mg}$ decreased latency to persistent sleep by $2.3 \mathrm{~min}$. (still not significant), but $20 \mathrm{mg}$ produced $22.3 \mathrm{~min}$. (32.3,12.3) improvement compared to placebo, a statistically significant benefit ${ }^{27}$. The effects of $10 \mathrm{mg}$ and $20 \mathrm{mg}$ on polysomnographic latency to persistent sleep were found to somewhat greater (and entirely statistically significant) if the preplanned cross-over-phase data of the study were retrospectively excluded ${ }^{31}$. Also, the $10 \mathrm{mg}$ dose reduced wake after sleep onset (WASO) by about 21 minutes at night 1 and after 4 weeks, which was statistically significant, and the $20 \mathrm{mg}$ dose similarly decreased WASO by 24.7 and $28.1 \mathrm{~min}$. respectively, both significant statistically ${ }^{31}$. Consequently, the $10 \mathrm{mg}$ dose improved sleep efficiency (percent of in-bed time asleep) by $5.2 \%$ on night 1 and $4.7 \%$ at the end of week 4 , and the $20 \mathrm{mg}$ dose improved sleep efficiency $7.6 \%$ and $10.4 \%$ respectively, all of which were statistically significant but of uncertain clinical significance, considering that the starting sleep efficiencies were $65 \%-66 \%^{27,31}$. By patient self-report, moreover, with $10 \mathrm{mg}$ and $20 \mathrm{mg}$ doses given at night 1 and ending the 4th week, neither the subjective sleep latency nor the subjective total sleep time were improved with statistical or clinical significance ${ }^{27}$. These patients tended to underestimate the modest objective benefits of suvorexant, so many patients will not be satisfied with either the recommended or the "not to exceed" dosage.

Oddly enough, whereas the patients fairly consistently reported more subjective benefits at the $40 \mathrm{mg}$ dose of suvorexant, that were both statistically and possibly clinically significant benefits $(30 \mathrm{mg}$ if age $\geq 65$ years), the polysomnographic data for $40 \mathrm{mg}$ showed unimpressive advantages at the end of 4 weeks compared to the lower doses, and the adverse effects were distinctly more common ${ }^{1,27}$. This may have been one reason why the FDA insisted on the lower starting dosage.

It is important to keep in mind that the three-month studies described at length in the current Belsomra Prescribing Information ${ }^{28,32}$ supported the small-magnitude efficacy of the "not to exceed" dosage of $20 \mathrm{mg}$ ( $15 \mathrm{mg}$ for age $\geq 65$ ), not the efficacy of the recommended starting dose. The modest efficacies were similar in the three-month studies to those for the $20 / 15 \mathrm{mg}$ group described in the multipledosage study described above. Though statistical significance was more robust in the three-month studies because of the larger group sizes, some of the outcomes still failed to achieve statistical significance at some time points. The recommended $10 \mathrm{mg}$ dose had not been included in the Phase III studies, perhaps another indication that $10 \mathrm{mg}$ was regarded as ineffective. The Phase IIB study 
described in the two previous paragraphs was the only randomized study reported that compared the $10 \mathrm{mg}, 20 \mathrm{mg}$, and $40 \mathrm{mg}$ doses along with placeboes ${ }^{27}$.

Overall, comparing suvorexant augmentations of sleep with those reported for the benzodiazepines and benzodiazepine agonists in an authoritative meta-analysis ${ }^{33}$, all of the hypnotic categories seemed to produce benefits (or lack of benefits) in a similar range. That meta-analysis even questioned whether the " $z$ " hypnotics significantly increased objective total sleep time ${ }^{33}$. After that meta-analysis, the FDA lowered the recommended doses for zolpidem and eszopiclone, but as with suvorexant, there are few controlled-trial results for the new lower recommended dosages. We do not know if the benefits of low-dose zolpidem and eszopiclone are as minimal as those of suvorexant. For example, the now-recommended $1 \mathrm{mg}$ dosage of eszopiclone was ineffective in many PSG contrasts ${ }^{34,35}$. Without randomized comparative trials, one cannot rationally determine whether suvorexant produces as much benefit as the recently-popular hypnotics at currentlyrecommended doses, since the participants' ages, baseline sleep characteristics, and other factors varied among separate trials, as did elements of the trial designs. One can imagine that suvorexant would be particularly effective for the subgroup of insomnia patients with daytime hyperarousal, but so far no evidence has been produced. I suspect that suvorexant produces better reduction of WASO than popular short-acting hypnotics (although less reduction of sleep latency), but medium-half-life hypnotics such as temazepam and low-dose doxepin might have similar WASO efficacy, and low-dose doxepin may have comparatively fewer adverse effects ${ }^{36,37}$. To summarize, for suvorexant, greater overall efficacy than generic competitors at the recommended dosages does not appear likely.

Suvorexant increases nocturnal sleep mainly by reducing WASO, similar to some alternative hypnotics, but unlike short-acting zaleplon, triazolam, or the standard-release zolpidem formulation. The suvorexant effect on the latency to fall asleep is quite weak at the recommended or "not to exceed" dosages due to slow absorption. Accordingly, suvorexant will be particularly unsatisfactory for patients primarily concerned with trouble falling asleep, but suvorexant may be preferred to the shortest-half-life hypnotics for patients who mainly complain of trouble staying asleep and early awakening i.e., WASO. Trouble staying asleep is more common than trouble falling asleep for patients over age 40, probably because circadian rhythms tend to peak progressively earlier from adolescence to old age unless dementia begins.

\section{Immediate risks of suvorexant and alternative hypnotics}

Suvorexant has some distinguishing risks, as well as most of the same immediate risks as the alternative hypnotics. Because suvorexant is not very rapidly absorbed (median $\mathrm{T}_{\max }$ of 2 hours, range $30 \mathrm{~min}$. to 6 hours, with further delay of approximately 1.5 hours after a high-fat meal) and has an average half-life of approximately 12 hours $^{28}$, a meaningful blood concentration usually persists throughout the day after prior-evening administration, and there is "an accumulation of approximately 1- to 2-fold with once-daily dosing, leading to an estimated $20 \%$ increase in the concentration after repeated dosing ${ }^{1,28}$. After 7 nights of administration, the suvorexant blood concentration remained so substantial during the day that just before the next evening dose, the lowest daytime concentration on the $7^{\text {th }}$ day was more than half the maximal concentration achieved at $\mathrm{T}_{\max }$ during the first night ${ }^{38}$. Since receptor binding and release of orexins is quite indolent, the actions of suvorexant on neurons perhaps lag even later than the plasma $\mathrm{T}_{\max }$ and the stated half-life might suggest ${ }^{4,39}$. Moreover, since suvorexant is mainly metabolized by CYP3A and CYP2C19 enzymes ${ }^{28}$, the actions of which may be augmented or reduced by common genetic variants ${ }^{40}$ and other drugs, half-life and daytime accumulation may be quite variable or idiosyncratic. In healthy young adults, the maximum first-night concentrations can vary two-fold, obese females have an approximate $20 \%$ increase in morning-after blood levels, and strong CYP3A inhibitors result in three times the drug area under the curve $^{1,38}$. Also, suvorexant might influence the metabolism of other drugs through CYP3A. The Prescribing Information recommends against use of suvorexant with strong CYP3A inhibitors ${ }^{28}$, but one may be skeptical how universally that caution can be observed.

Evidently, the FDA intends that the $5 \mathrm{mg}$ dosage be chosen for those using moderate CYP3A inhibitors or for patients who appear not to tolerate $10 \mathrm{mg}$ well, whereas other patients may need the $20 \mathrm{mg}$ dosage $^{29}$. Above a $20 \mathrm{mg}$ dosage, the FDA analysis concluded that benefits did not increase in proportion to the strong increase in disturbing adverse effects at the higher dosages. In 30-40 mg dosage groups, $2.8 \%$ of patients discontinued use within 3 months due to somnolence, fatigue, sedation, and lethargy combined, and additionally $0.2 \%$ also discontinued due to each of the following: nightmares, sleep paralysis, memory impairment, and depression ${ }^{1}$. In the 15-20 mg groups, the discontinuation rate for adverse events was only $0.6 \%$ as compared to $0.4 \%$ for placebo ${ }^{1}$.

As an orexin receptor antagonist, suvorexant appears to produce occasional narcolepsy-like symptoms, especially in the notrecommended $40 \mathrm{mg}$ dosage, such as rare cataplexy (sudden weakness or paralysis), sleep paralysis, hypnagogic or hypnopompic hallucinations, and disturbing dreams ${ }^{1}$. Suvorexant seems unique among approved hypnotics in its narcolepsy-like adverse effects that can be frightening or temporarily disabling for a very small percentage of patients.

Like most hypnotics with half-lives exceeding 3-6 hours, suvorexant causes daytime somnolence and fatigue among a percentage of users, but suvorexant in recommended doses did not appear to cause reported daytime somnolence more often than alternative hypnotics. In the Phase III trials, some patients suffered disabling sleepiness while driving the following morning. Driving impairments tended to be more severe with zopiclone $7.5 \mathrm{mg}$ than with suvorexant $20 \mathrm{mg}$ or $40 \mathrm{mg}$ ( $30 \mathrm{mg}$ if age $\geq 65$ years), but it was estimated that suvorexant might impair 10\%-20\% of adult patients on a driving test as much as would a blood alcohol level of $0.05-0.08^{1}$. Note that zopiclone $7.5 \mathrm{mg}$ contains about $3.75 \mathrm{mg}$ eszopiclone, and patients and their physicians approaching such doses must be cautious of potential driving impairment. As with other hypnotics, it may be assumed that this daytime somnolence and these performance impairments can be augmented by combinations of suvorexant with other sedative drugs, narcotics, or alcohol ${ }^{38}$ that were generally 
avoided by participants selected for controlled trials. According to the Prescribing Information ${ }^{28}$, a variety of mental and behavioral impairments may occasionally occur among patients taking suvorexant such as amnesia, anxiety, hallucinations, and complex sleep behaviors. Symptoms of this kind, of which "zombie driving" is an example, occur with other hypnotics and have become somewhat notorious with triazolam and zolpidem ${ }^{41-44}$.

In the preapproval trials, suicidal ideation appeared to be a distinct risk of suvorexant, almost entirely at the $30-40 \mathrm{mg}$ dosage level $(0.6 \%)^{1}$. That should not be surprising, since suvorexant causes short REM sleep latency ${ }^{1}$, as is also associated with narcolepsy and depression, and narcolepsy is often treated with antidepressants ${ }^{45}$. Considering that orexin is increased during pleasure and inhibited during pain, one theory is that a link between narcolepsy and depression results from a changed balance of dynorphin and orexin $^{7}$. Depression and suicide are likewise associated with many other hypnotics, based on both controlled trials demonstrating causality and epidemiologic studies ${ }^{46,47}$.

In a one-year controlled trial of suvorexant $30-40 \mathrm{mg}$ versus placebo, those randomized to suvorexant experienced a dramatic increase in time to sleep onset, once the drug was withdrawn, so that even at the end of two months' drug-free follow-up, the sleep latency of suvorexant-withdrawn patients was subjectively 10-12 min. worse than that of patients who had previously received placebo throughout ${ }^{48,49}$. Simply comparing the subjectively-reported sleep of participants while receiving suvorexant vs placebo to the drugfree follow-ups, this withdrawal effect was glaringly apparent. Clinical trial investigators denied that "rebound" was a problem, having relied on a drug "rebound" criterion biased against demonstrating withdrawal effects and lacking statistical power ${ }^{50}$. Nevertheless, it is to the investigators' credit that they obtained a long two-month post-drug follow-up. This was the longest-lasting randomized, controlled demonstration of hypnotic-withdrawal insomnia of which I am aware ${ }^{48}$. Certainly, popular alternative hypnotics also produce drug-withdrawal insomnia ${ }^{22,49}$, but their withdrawal liabilities have not been studied with equivalent designs. Zolpidem $10 \mathrm{mg}$ caused no appreciable problem in a 1-year study of somewhat different design with a somewhat anomalous outcome ${ }^{51}$. We do not know which drugs would cause more withdrawal distress given at the recommended dosages.

Some hypnotics cause increased infections in randomized controlled trials, supported by extensive epidemiology $y^{52-55}$. When given suvorexant, patient infections and infestations overall were about equal with placebo, but there was a dose-response trend for more common "URI" reports among participants receiving suvorexant than placebo $^{1}$. The controlled trial evidence for causing infections would appear stronger for alternative hypnotics than for suvorexant.

To examine effects of suvorexant on nocturnal respiration, patients with COPD and "moderate" sleep apnea were randomized to suvorexant $40 \mathrm{mg}$ ( $30 \mathrm{mg}$ if age $\geq 65$ years) or placebo for 4-night sleep recordings. Participants had a mean $\mathrm{SpO}_{2}$ of $>94 \%$ awake and $>93 \%$ during sleep, and mean BMI of 25.9. Nevertheless, suvorexant produced significantly reduced $\mathrm{SpO}_{2}$ both during wake and during sleep, and increased time below $85 \% \mathrm{SpO}_{2}$, though these effects were quite small and were not considered clinically significant ${ }^{56}$. In a study of participants with "mild or moderate" sleep apnea and with average age 49, night 4 AHI (apnea-hypopnea index) was increased from 14.41 to 17.07 events per hour with suvorexant versus placebo, a difference of 2.66 (0.22 to 5.09), therefore significant ${ }^{57}$. Though these adverse effects did not appear clinically significant on average, in both studies suvorexant did impair nocturnal breathing. These were not the sorts of patients whose nocturnal breathing would be most vulnerable to a hypnotic and of greatest concern, e.g., those with marked nocturnal oxygen desaturation, obesity, and concomitant use of narcotics ${ }^{58}$ or other sedatives. Since alternative hypnotics also depress nocturnal respiration, it is unclear if suvorexant causes more respiratory risk than the alternatives.

Falls are strongly associated with use of many hypnotics ${ }^{59-61}$, but falls among patients randomized to suvorexant were no more common than those among participants randomized to placebo ${ }^{1}$.

Like most benzodiazepine-agonist hypnotics, suvorexant is thought to have some addiction potential and is rated Schedule IV by the $\mathrm{DEA}^{62}$. In contrast, doxepin, antihistamines, and melatonin are not controlled by the DEA.

To summarize, it seems unlikely that suvorexant could prove superior to alternative hypnotics in comparative trials focusing on the immediate benefits/risks ratios, because of 1) weak subjective benefit at low doses, 2) weak polysomnographic benefit for reducing sleep latency, 3) a relatively long half-life resulting in accumulation and daytime sedation, 4) particularly variable rates of absorption and CYP3A metabolism making dosing unpredictable, and 5) relatively unique narcolepsy-like symptoms with more-thanrecommended doses. On the other hand, the long-term effects of hypnotics might be more important than their immediate effects.

\section{Long-term benefits and risks of suvorexant and alternative hypnotics}

Most patients who receive a prescription for a hypnotic consume the drug for only a brief time. However, the unusual patient who consumes a hypnotic nightly or several times a week for years receives so many prescriptions, that these heavy users consume most of the hypnotic drug market ${ }^{63,64}$. Among long-term habitual hypnotic consumers, there is a need to consider hypnotic benefits and risks not only for sleep but also for the long-term risks of dementia, cancer, and mortality. Unfortunately, there have been no long-term controlled trials assessing years of hypnotic usage by contrasting samples randomized to a hypnotic versus placebo, or comparing different hypnotics randomly assigned. Trials of cardiology drugs such as statins or the Women's Health Initiative long-term trial of estrogens assessed years of drug usage among tens of thousands of participants, but we have no comparable controlled trials of hypnotics.

The body tends to clear amyloid- $\beta$ from brain intercellular regions during sleep, a process that may be inhibited during wakefulness by orexin $^{65-69}$. This has led to speculation that orexin antagonists, such as suvorexant, might hypothetically reduce risks of Alzheimer's disease. However, one small study found evidence of an average amount of Alzheimer's amyloid plaque accumulation in brains of aged narcoleptics ${ }^{70}$. Further, suvorexant in the recommended dosages 
increases total sleep rather little, and the increment is mainly REM sleep rather than deep sleep ${ }^{4}$. Since it appears to be non-REM sleep that is associated with amyloid- $\beta$ clearance rather than orexin itself $^{68}$, any idea that suvorexant would have a beneficial effect on amyloid- $\beta$ may be wishful thinking ${ }^{70}$. In contrast, there is more persuasive evidence that prior use of benzodiazepine-agonist hypnotics is associated with future Alzheimer's dementia ${ }^{71-73}$. Causality has not been proven.

There is suggestive evidence from small controlled trials that benzodiazepine-agonist hypnotics cause cancer. In a group of rather small controlled trials reviewed by the FDA, 13 incident cancer cases (mainly skin cancers) were found among patients randomized to hypnotics, but none were found among the sometimes-smaller randomized placebo groups ${ }^{74}$. Further, epidemiologic studies have supported an association of prior hypnotic use with cancer incidence ${ }^{64,75,76}$. It is controversial whether the presence of epidemiologic association might imply that benzodiazepine-agonist hypnotics cause cancer ${ }^{77,78}$. In the distinct case of suvorexant, my tabulation of the suvorexant randomized controlled trials reported to ClinicalTrials.gov (www.ClinicalTrials.gov) indicated no incident malignancies among 493 participants receiving suvorexant $20 \mathrm{mg}$ ( $15 \mathrm{mg}$ if age $\geq 65$ years), 9 incident malignancies among 1291 participants receiving suvorexant $40 \mathrm{mg}$ ( $30 \mathrm{mg}$ if age $\geq 65$ years), and 9 malignancies among 1025 participants randomized to placebo. Thus, incident cancers were less frequent among those randomized to suvorexant, particularly less than $30 \mathrm{mg}$ as compared to placebo. These differences in cancer incidence were not statistically reliable in the suvorexant trials for these very infrequent cancer events. The FDA's approach to enumerating the incident neoplasms in suvorexant controlled trials produced slightly different tabulations, but essentially similar trends were described ${ }^{1}$. In summary, more data are needed, but there is a possibility that benzodiazepine agonist hypnotics are carcinogenic whereas suvorexant is not. Even the possibility that suvorexant is anti-neoplastic cannot be excluded.

Finally, there are now more than 20 epidemiologic studies showing that use of benzodiazepine-agonists and diphenhydramine has been significantly associated with excess mortality, with hazard ratios as high as 3 to $5^{64,79-81}$. A much smaller number of studies has observed no significant survival risk associated with hypnotics use, but no published studies yet have suggested any evidence that use of hypnotics improves survival. Indeed, some studies suggest that hypnotics have posed as much mortality risk as cigarettes ${ }^{64,79,82}$. Despite various efforts of many investigators to control for potential confounding in epidemiologic studies, it remains possible that this strong risk association is entirely due to statistical confounding, reflecting no causality ${ }^{83}$. A persuasive demonstration of mortality causation could only come from long-term randomized controlled trials or perhaps Mendelian randomization studies. At present, there is no epidemiologic evidence whether suvorexant use is associated with increased or decreased survival. There is as yet no evidence base permitting a guess about how suvorexant compares with alternative hypnotics for association with mortality.

\section{Conclusions}

With the limited available evidence, we can only guess about whether suvorexant is more or less effective and more or less safe than popular prescription hypnotics. However, none of them are very effective for increasing objective sleep or for improving daytime performance. Apart from some very small unpublished Phase II trials focused on special risks, there have been no randomized comparative trials examining whether the suvorexant benefits/risks ratio is better or worse than that of popular alternatives, so there are no bases for a clear preference save the amount of prior experience and costs. One might suppose that had the developers thought that suvorexant was superior in its immediate effects, they would have performed comparative clinical trials to highlight the advantages. Currently, suvorexant appears more expensive than many popular generic hypnotics. Suvorexant has so-far undergone little Phase IV safety surveillance. It appears that the overall balance of immediate benefits and risks with suvorexant most likely would be comparable or inferior to alternative hypnotics such as zolpidem (Table 2). As to long-term benefits and risks, we will have to hope that the industry conducts the necessary long-term comparative trials to assess which hypnotic compounds are safest and most beneficial.

Table 2 summarizes some evidence concerning how suvorexant might compare with zolpidem, currently the most popular hypnotic in the United States. The comparisons for long-term risks and benefits are pure speculation.

\section{The future choice of the best hypnotics}

There are other orexin receptor antagonists in development. Possibly, a new orexin receptor antagonist will become available as a hypnotic with more reliable pharmacokinetics than suvorexant and a shorter $\mathrm{T}_{\max }$ and half-life. Perhaps such a drug might safely be given in a more effective bedtime dosage, with less danger of daytime adverse effects. A focus of future study will be how orexin receptor antagonists compare with alternative treatments of disturbed sleep such as cognitive behavioral treatment of insomnia or bright light treatment. There is a growing consensus that current data favor cognitive-behavioral therapy over hypnotics, and bright light may be superior for particular circadian rhythm sleep disorders manifesting as insomnia.

Looking forward, I anticipate that better-organized exploitation of electronic medical records will produce increasing scrutiny of effects of hypnotics on inpatient falls, infections, and length of stay. Likewise, there will be increasing examination of the association of hypnotics with outpatient readmissions, infections, dementia, cancer, and mortality. Increasing use of genome-wide-association studies, exome sequencing, and whole-genome sequencing will make it possible to do Mendelian randomization studies that assess the causality of hypnotic associations with excess depression, infection, cancer, and mortality. Unfortunately, it will be many years before experience will be collected sufficient to apply Mendelian randomization strategies to orexin receptor antagonists. It is only speculation that in regard to long-term risks, particularly dementia, cancer, 
Table 2. Comparison of suvorexant and zolpidem: likely benefits and risks.

\begin{tabular}{|c|c|c|c|}
\hline & $\begin{array}{c}\text { possibly } \\
\text { suvorexant } \\
\text { better }\end{array}$ & $\begin{array}{c}\text { possibly } \\
\text { zolpidem } \\
\text { better }\end{array}$ & $\begin{array}{c}\text { not enough } \\
\text { data to } \\
\text { guess }\end{array}$ \\
\hline \multicolumn{4}{|l|}{ Immediate Benefits } \\
\hline decreased sleep latency & & X & \\
\hline decreased wake after sleep onset & $X$ & & \\
\hline increased total nightly sleep & & & $x$ \\
\hline \multicolumn{4}{|l|}{ Immediate Risks } \\
\hline daytime sleepiness and fatigue & & & $x$ \\
\hline impaired driving & & $x$ & \\
\hline impaired performance & & $x$ & \\
\hline narcoleptiform symptoms & & $x$ & \\
\hline amnesia, anxiety, hallucinations & & & $x$ \\
\hline complex sleep behaviors & & & $x$ \\
\hline depression and suicidal thoughts & & & $x$ \\
\hline withdrawal insomnia & & $x$ & \\
\hline infections & $X$ & & \\
\hline respiratory depression & & & $x$ \\
\hline falls & $x$ & & \\
\hline addiction/abuse potential & & & $X$ \\
\hline \multicolumn{4}{|l|}{ Long-term Risks \& Benefits } \\
\hline dementia & $?$ & & \\
\hline cancer & $?$ & & \\
\hline mortality vs survival & & & $?$ \\
\hline
\end{tabular}

$\mathbf{X}$ Based on somewhat-parallel placebo-controlled-trials studies but no comparative-trials studies

? Based only on non-comparative epidemiology and scientific speculation

and mortality, suvorexant might be found safer than alternatives or even beneficial. Unless and until the industry can provide us with long-term-trials evidence of more distinct suvorexant advantages, cautious and cost-conscious physicians and their patients may prefer the alternatives.

\section{Competing interests}

Since 1979 publication of hypnotics epidemiology from the American Cancer Society CPSI study ${ }^{84}$, the author has been a frequent critic of hypnotics risks and benefits, especially through his non-profit internet web site, www.DarkSideOfSleepingPills.com, that provides readers with more extensive information and references about risks of hypnotics. Dr. Kripke's family owns stock and options in a large conglomerate that in turn invested a tiny percentage of its capital in Sanofi-Aventis stock. The author has no relevant affiliations or financial involvement with any organization or entity with a financial interest in or financial conflict with the subject matter or materials discussed in the manuscript. This includes employment, consultancies, honoraria, other stock ownership or options, expert testimony, grants or patents received or pending or royalties. No writing assistance was utilized in the production of this manuscript.

\section{Grant information}

The author(s) declared that no grants were involved in supporting this work.

\section{Acknowledgements}

Several boarded sleep specialists at the Scripps Clinic Viterbi Family Sleep Center kindly read and provided comments on a previous draft of this manuscript. 
1. Farkas RH, Katz R, Illoh K, et al:: Application Number 2045690rig1s000: Medical Review(s). 2013

Reference Source

2. Mignot E: Sleep, sleep disorders and hypocretin (orexin). Sleep Med. 2004 5(Suppl 1): S2-S8.

PubMed Abstract | Publisher Full Text

3. Mieda M, Sakurai T: Orexin (hypocretin) receptor agonists and antagonists for treatment of sleep disorders. Rationale for development and current status. CNS Drugs. 2013; 27(2): 83-90.

PubMed Abstract | Publisher Full Text

4. Jacobson LH, Callander GE, Hoyer D: Suvorexant for the treatment of insomnia Expert Rev Clin Pharmacol. 2014; 7(6): 711-30.

PubMed Abstract | Publisher Full Tex

5. Alexandre C, Andermann ML, Scammell TE: Control of arousal by the orexin neurons. Curr Opin Neurobiol. 2013; 23(5): 752-9.

PubMed Abstract | Publisher Full Text | Free Full Text

6. Nishino S, Sakurai E, Nevsimalova S, et al.: Decreased CSF histamine in narcolepsy with and without low CSF hypocretin-1 in comparison to healthy controls. Sleep. 2009; 32(2): 175-80.

PubMed Abstract | Free Full Text

7. Shan L, Dauvilliers $Y$, Siegel JM: Interactions of the histamine and hypocretin systems in CNS disorders. Nat Rev Neurol. 2015; 11(7): 401-13. PubMed Abstract | Publisher Full Text

8. Lin JS: Brain structures and mechanisms involved in the control of cortical activation and wakefulness, with emphasis on the posterior hypothalamus and histaminergic neurons. Sleep Med Rev. 2000; 4(5): 471-503.

PubMed Abstract | Publisher Full Text

9. Saper CB: The neurobiology of sleep. Continuum (Minneap Minn). 2013; 19(1 Sleep Disorders): 19-31. PubMed Abstract

10. Ollila HM, Ravel JM, Han F, et al.: HLA-DPB1 and HLA class I confer risk of and protection from narcolepsy. Am J Hum Genet. 2015; 96(1): 136-46. PubMed Abstract | Publisher Full Text | Free Full Text

11. Mahlios J, De la Herrán-Arita AK, Mignot E: The autoimmune basis of narcolepsy. Curr Opin Neurobiol. 2013; 23(5): 767-73. PubMed Abstract | Publisher Full Text | Free Full Text

12. Faraco J, Lin L, Kornum BR, et al.: ImmunoChip study implicates antigen presentation to T cells in narcolepsy. PLoS Genet. 2013; 9(2): e1003270. PubMed Abstract | Publisher Full Text | Free Full Text

13. Ahmed SS, Volkmuth W, Duca J, et al:: Antibodies to influenza nucleoprotein cross-react with human hypocretin receptor 2. Sci Transl Med. 2015; 7(294): 294ra105.

PubMed Abstract | Publisher Full Text

14. Parker I: THE BIG SLEEP: insomnia drugs like Ambien are notorious for their side effects. Has Merck created a blockbuster replacement? The New Yorker. 2013: 50-63.

Reference Source

15. Mignot E: Physiology. The perfect hypnotic? Science. 2013; 340(6128): 36-8. PubMed Abstract | Publisher Full Text

16. Rogers AE, Aldrich MS, Caruso CC: Patterns of sleep and wakefulness in treated narcoleptic subjects. Sleep. 1994; 17(7): 590-7. PubMed Abstract

17. Thorpy M: Current concepts in the etiology, diagnosis and treatment of narcolepsy. Sleep Med. 2001; 2(1): 5-17. PubMed Abstract | Publisher Full Text

18. Johnson LC, Chernik DA: Sedative-hypnotics and human performance. Psychopharmacology (Berl). 1982; 76(2): 101-13. PubMed Abstract | Publisher Full Text

19. Verster JC, Veldhuijzen DS, Patat A, et al:: Hypnotics and driving safety: metaanalyses of randomized controlled trials applying the on-the-road driving test. Curr Drug Saf. 2006; 1(1): 63-71. PubMed Abstract | Publisher Full Text

20. Boyle J, Groeger JA, Paska W, et al:: A method to assess the dissipation of the [corrected] residual effects of [corrected] hypnotics: eszopiclone versus zopiclone. J Clin Psychopharmacol. 2012; 32(5): 704-9. PubMed Abstract | Publisher Full Text

21. Tan TL, Bixler EO, Kales A, et al.: Early morning insomnia, daytime anxiety, and organic mental disorder associated with triazolam. J Fam Pract. 1985; 20(6) 592-4. PubMed Abstract

22. Walsh JK, Roth T, Randazzo A, et al.: Eight weeks of non-nightly use of zolpidem for primary insomnia. Sleep. 2000; 23(8): 1087-96. PubMed Abstract

23. Zemlan FP, Mulchahey J, Scharf MB, et al:: The efficacy and safety of the melatonin agonist beta-methyl-6-chloromelatonin in primary insomnia: a randomized, placebo-controlled, crossover clinical trial. J Clin Psychiatry. 2005; 66(3): 384-90.

PubMed Abstract | Publisher Full Text

24. Luthringer R, Muzet M, Zisapel N, et al.: The effect of prolonged-release melatonin on sleep measures and psychomotor performance in elderly patients with insomnia. Int Clin Psychopharmacol. 2009; 24(5): 239-49. PubMed Abstract | Publisher Full Text

25. Wade AG, Farmer M, Harari G, et al: Add-on prolonged-release melatonin for cognitive function and sleep in mild to moderate Alzheimer's disease: a 6-month, randomized, placebo-controlled, multicenter trial. Clin Interv Aging. 2014; 9: 947-61.

PubMed Abstract | Publisher Full Text | Free Full Text

26. Rossignol DA, Frye RE: Melatonin in autism spectrum disorders: a systematic review and meta-analysis. Dev Med Child Neurol. 2011; 53(9): 783-92. PubMed Abstract | Publisher Full Text

27. Herring WJ, Snyder E, Budd K, et al:: Orexin receptor antagonism for treatment of insomnia: a randomized clinical trial of suvorexant. Neurology. 2012; 79(23): 2265-74.

PubMed Abstract | Publisher Full Text

28. Merck Sharp \& Dohme Corp.: BELSOMRA Prescribing Information. Whitehouse Station, NJ, Merck Sharp \& Dohme. 2014.

Reference Source

29. Unger EF: Office Director Decisional Memo. 2014 Reference Source

30. various. WebMD User Reviews \& Ratings - Belsomra orgal. 2015 Reference Source

31. Merck Sharp \& Dohme Corp.: Phase IIB 2-Period Crossover Polysomnography Study in Participants With Primary Insomnia (MK-4305-006). Bethesda, MD, U.S. National Institutes of Health. 2015 Reference Source

32. Herring WJ, Connor KM, Ivgy-May N, et al:: Suvorexant in Patients with Insomnia: Results from Two 3-Month Randomized Controlled Clinical Trials. Biol Psychiatry. 2014, in press; pii: S0006-3223(14)00762-8. PubMed Abstract | Publisher Full Text

33. Buscemi N, Vandermeer B, Friesen C, et al:: The efficacy and safety of drug treatments for chronic insomnia in adults: a meta-analysis of RCTs. $J$ Gen Intern Med. 2007; 22(9): 1335-50.

PubMed Abstract | Publisher Full Text | Free Full Text

34. Rosenberg R, Caron J, Roth T, et al:: An assessment of the efficacy and safety of eszopiclone in the treatment of transient insomnia in healthy adults. Sleep Med. 2005; 6(1): 15-22.

PubMed Abstract | Publisher Full Text

35. Scharf M, Erman M, Rosenberg R, et al.: A 2-week efficacy and safety study of eszopiclone in elderly patients with primary insomnia. Sleep. 2005; 28(6) 720-7.

PubMed Abstract

36. Rojas-Fernandez $\mathrm{CH}$, Chen $\mathrm{Y}$ : Use of ultra-low-dose ( $\leq 6 \mathrm{mg})$ doxepin for treatment of insomnia in older people. Can Pharm J (Ott). 2014; 147(5): 281-9. PubMed Abstract | Publisher Full Text | Free Full Text

37. Katz R, Farkas R, Cai J: Application Number: 022036Orig1s00: Medical Reviews (FDA). Accessed 12-4-2009

38. Dimova H, Brar S, Men A: Application Number: 204569Orig1s000: Clinical Pharmacology And Biopharmaceutics Review(s). 2014.

Reference Source

39. Callander GE, Olorunda M, Monna D, et al:: Kinetic properties of "dual" orexin receptor antagonists at $\mathrm{OX}_{1} \mathbf{R}$ and $\mathrm{OX}_{2} \mathrm{R}$ orexin receptors. Front Neurosci. 2013; 7: 230.

PubMed Abstract | Publisher Full Text | Free Full Text

40. Shen $M$, Shi $Y$, Xiang $P: C_{3} P_{3} A_{4}$ and $C Y P_{2} C_{19}$ genetic polymorphisms and zolpidem metabolism in the Chinese Han population: a pilot study. Forensic Sci Int. 2013; 227(1-3): 77-81.

PubMed Abstract | Publisher Full Text

41. Tsai JH, Yang P, Chen CC, et al:: Zolpidem-induced amnesia and somnambulism: rare occurrences? Eur Neuropsychopharmacol. 2009; 19(1): $74-6$. PubMed Abstract | Publisher Full Text

42. Pressman MR: Sleep driving: Sleepwalking variant or misuse of z-drugs? Sleep Med Rev. 2011; 15(5): 285-92.

PubMed Abstract | Publisher Full Text

43. Poceta JS: Zolpidem ingestion, automatisms, and sleep driving: a clinical and legal case series. J Clin Sleep Med. 2011; 7(6): 632-8. PubMed Abstract | Publisher Full Text | Free Full Text

44. Morgenthaler TI, Silber MH: Amnestic sleep-related eating disorder associated with zolpidem. Sleep Med. 2002; 3(4): 323-7. PubMed Abstract | Publisher Full Text

45. Vignatelli L, D'Alessandro R, Candelise L: Antidepressant drugs for narcolepsy Cochrane Database Syst Rev. 2008; (1): CD003724.

PubMed Abstract | Publisher Full Text

46. Kripke DF: Greater incidence of depression with hypnotic use than with placebo. BMC Psychiatry. 2007; 7: 42.

PubMed Abstract | Publisher Full Text | Free Full Text

47. Gunnell D, Chang SS, Tsai MK, et al:: Sleep and suicide: an analysis of a cohort of 394,000 Taiwanese adults. Soc Psychiatry Psychiatr Epidemiol. 2013; 48(9): 1457-65.

PubMed Abstract | Publisher Full Text 
48. Michelson D, Snyder E, Paradis E, et al.: Safety and efficacy of suvorexant during 1-year treatment of insomnia with subsequent abrupt treatment discontinuation: a phase 3 randomised, double-blind, placebo-controlled trial. Lancet Neurol. 2014; 13(5): 461-71.

PubMed Abstract | Publisher Full Text

49. Kripke DF: Hypnotics cause insomnia: evidence from clinical trials. Sleep Med 2014; 15(9): 1168-9.

PubMed Abstract | Publisher Full Text

50. Kripke DF: "Rebound" is not an appropriate criterion for withdrawal insomnia. Sleep Med. 2014; 15(12): 1594. PubMed Abstract | Publisher Full Text

51. Roehrs TA, Randall S, Harris E, et al:: Twelve months of nightly zolpidem does not lead to rebound insomnia or withdrawal symptoms: a prospective placebo-controlled study. J Psychopharmacol. 2012; 26(8): 1088-95. PubMed Abstract | Publisher Full Text | Free Full Text

52. Joya FL, Kripke DF, Loving RT, et al.: Meta-analyses of hypnotics and infections: eszopiclone, ramelteon, zaleplon, and zolpidem. J Clin Sleep Med. 2009; 5(4): 377-83.

PubMed Abstract | Free Full Text

53. Obiora $\mathrm{E}$, Hubbard R, Sanders RD, et al: The impact of benzodiazepines on occurrence of pneumonia and mortality from pneumonia: a nested casecontrol and survival analysis in a population-based cohort. Thorax. 2013; 68(2): 163-70.

PubMed Abstract | Publisher Full Text

54. Iqbal U, Syed-Abdul S, Nguyen PA, et al:: The impact of benzodiazepines on occurrence of pneumonia and mortality from pneumonia: a nested casecontrol and survival analysis in a population-based cohort. Thorax. 2013; 68(6): $591-2$.

PubMed Abstract | Publisher Full Text

55. Huang $\mathrm{CY}$, Chou FH, Huang YS, et al:: The association between zolpidem and infection in patients with sleep disturbance. J Psychiatr Res. 2014; 54(7): $116-20$

PubMed Abstract | Publisher Full Text

56. Sun H, Palcza J, Rosenberg R, et al:: Effects of suvorexant, an orexin receptor antagonist, on breathing during sleep in patients with chronic obstructive pulmonary disease. Respir Med. 2015; 109(3): 416-26.

PubMed Abstract | Publisher Full Text

57. Merck Sharp \& Dohme Corp.: Effects of suvorexant in participants with obstructive sleep apnea (MK-4305-036). Bethesda, MD, National Institutes of Health. ClinicalTrials.gov NCT01300455. 2015. Reference Source

58. Webster LR, Choi $Y$, Desai $\mathrm{H}$, et al.: Sleep-disordered breathing and chronic opioid therapy. Pain Med. 2008; 9(4): 425-32. PubMed Abstract | Publisher Full Text

59. Diem SJ, Ewing SK, Stone KL, et al:: Use of non-benzodiazepine sedative hypnotics and risk of falls in older men. J Gerontol Geriatr Res. 2014; 3(3): 158 PubMed Abstract | Publisher Full Text | Free Full Text

60. Berry SD, Lee Y, Cai S, et al:: Nonbenzodiazepine sleep medication use and hip fractures in nursing home residents. JAMA Intern Med. 2013; 173(9): 754-61. PubMed Abstract | Publisher Full Text | Free Full Text

61. Kolla BP, Lovely JK, Mansukhani MP, et al:: Zolpidem is independently associated with increased risk of inpatient falls. J Hosp Med. 2013; 8(1): 1-6. PubMed Abstract | Publisher Full Text

62. Harrigan TM: Schedules of controlled substances: Placement of Suvorexant into Schedule IV. 21 CFR Part 1308 [Docket No. DEA-381], Washington, D.C., Federal Register. Accessed 8-28-2014; 79(167); 51243-51247. Reference Source

63. Kripke DF, Garfinkel L, Wingard DL, et al.: Mortality associated with sleep duration and insomnia. Arch Gen Psychiatry. 2002; 59(2): 131-6. PubMed Abstract | Publisher Full Text

64. Kripke DF, Langer RD, Kline LE, et al:: Hypnotics' association with mortality or cancer: a matched cohort study. BMJ Open. 2012; 2(1): e000850. PubMed Abstract | Publisher Full Text | Free Full Text

65. Kang JE, Lim MM, Bateman RJ, et al.: Amyloid-beta dynamics are regulated by orexin and the sleep-wake cycle. Science. 2009; 326(5955): 1005-7. PubMed Abstract | Publisher Full Text | Free Full Text
66. Liguori C, Romigi A, Nuccetelli M, et al:: Orexinergic system dysregulation, sleep impairment, and cognitive decline in Alzheimer disease. JAMA Neurol. 2014; 71(12): 1498-505

PubMed Abstract | Publisher Full Text

67. Xie $\mathrm{L}$, Kang $\mathrm{H}, \mathrm{Xu}$ Q, et al.: Sleep drives metabolite clearance from the adult brain. Science. 2013; 342(6156): 373-7.

PubMed Abstract | Publisher Full Text | Free Full Text

68. Roh $\mathrm{JH}$, Jiang $\mathrm{H}$, Finn MB, et al.: Potential role of orexin and sleep modulation in the pathogenesis of Alzheimer's disease. J Exp Med. 2014; 211(13): 2487-96. PubMed Abstract | Publisher Full Text | Free Full Text

69. Dauvilliers YA, Lehmann S, Jaussent I, et al:: Hypocretin and brain $\beta$-amyloid peptide interactions in cognitive disorders and narcolepsy. Front Aging Neurosci. 2014; 6: 119 .

PubMed Abstract | Publisher Full Text | Free Full Text

70. Scammell TE, Matheson JK, Honda M, et al.: Coexistence of narcolepsy and Alzheimer's disease. Neurobiol Aging. 2012; 33(7): 1318-9. PubMed Abstract | Publisher Full Text

71. Chen PL, Lee WJ, Sun WZ, et al.: Risk of dementia in patients with insomnia and long-term use of hypnotics: a population-based retrospective cohort study. PLoS One. 2012; 7(11): e49113. PubMed Abstract | Publisher Full Text | Free Full Text

72. Billioti de Gage S, Bégaud B, Bazin F, et al:: Benzodiazepine use and risk of dementia: prospective population based study. BMJ. 2012; 345: e6231. PubMed Abstract | Publisher Full Text | Free Full Text

73. Billioti de Gage S, Moride $\mathrm{Y}$, Ducruet $\mathrm{T}$, et al:: Benzodiazepine use and risk of Alzheimer's disease: case-control study. BMJ. 2014; 349: g5205. PubMed Abstract | Publisher Full Text | Free Full Text

74. Kripke DF: Possibility that certain hypnotics might cause cancer in skin. J Sleep Res. 2008; 17(3): 245-50. PubMed Abstract | Publisher Full Text

75. Kao CH, Sun LM, Liang JA, et al:: Relationship of zolpidem and cancer risk: a Taiwanese population-based cohort study. Mayo Clin Proc. 2012; 87(5): 430-6. PubMed Abstract | Publisher Full Text | Free Full Text

76. $\mathrm{Kao} \mathrm{CH}$, Sun LM, Su KP, et al.: Benzodiazepine use possibly increases cancer risk: a population-based retrospective cohort study in Taiwan. J Clin Psychiatry. 2012; 73(4): e555-e560. PubMed Abstract | Publisher Full Text

77. Pottegård A, Friis S, Andersen M, et al:: Use of benzodiazepines or benzodiazepine related drugs and the risk of cancer: a population-based casecontrol study. Br J Clin Pharmacol. 2013; 75(5): 1356-64. PubMed Abstract | Publisher Full Text | Free Full Text

78. Kripke DF, Langer RD: Evidence for harm, comment on 'Use of benzodiazepines or benzodiazepine related drugs and the risk of cancer: a population-based case-control study'. Br J Clin Pharmacol. 2014; 78(1): 186-7. PubMed Abstract | Publisher Full Text | Free Full Text

79. Mallon L, Broman JE, Hetta J: Is usage of hypnotics associated with mortality? Sleep Med. 2009; 10(3): 279-86.

PubMed Abstract | Publisher Full Text

80. Weich $S$, Pearce HL, Croft $P$, et al.: Effect of anxiolytic and hypnotic drug prescriptions on mortality hazards: retrospective cohort study. BMJ. 2014; 348 g1996.

PubMed Abstract | Publisher Full Text | Free Full Text

81. Chen HC, Su TP, Chou P, et al:: A nine-year follow-up study of sleep patterns and mortality in community-dwelling older adults in Taiwan. Sleep. 2013; 36(8): 1187-98.

PubMed Abstract | Publisher Full Text | Free Full Text

82. Kripke DF, Klauber MR, Wingard DL, et al:: Mortality hazard associated with prescription hypnotics. Biol Psychiatry. 1998; 43(9): 687-93. PubMed Abstract | Publisher Full Text

83. Levine M: ACP Journal Club. Hypnotic drugs were associated with increased risk for mortality. Ann Intern Med. 2012; 156(12): JC6-13. PubMed Abstract | Publisher Full Text

84. Kripke DF, Simons RN, Garfinkel L, et al.: Short and long sleep and sleeping pills. Is increased mortality associated? Arch Gen Psychiatry. 1979; 36(1): 103-16.

PubMed Abstract | Publisher Full Text 


\section{Open Peer Review}

\section{Current Peer Review Status:}

\section{Version 1}

Reviewer Report 18 September 2015

https://doi.org/10.5256/f1000research.7359.r10375

(C) 2015 Sivertsen B. This is an open access peer review report distributed under the terms of the Creative Commons Attribution License, which permits unrestricted use, distribution, and reproduction in any medium, provided the original work is properly cited.

\section{Børge Sivertsen}

Division of Mental Health, Norwegian Institute of Public Health, Bergen, Norway

Title and Abstract: The title and abstract is well formulated and indeed representative for the rest of the full text paper. Being an opinion article, it is made clear from the beginning including the abstract - that no new original data are presented; rather an expert's summarization of available evidence regarding the use of suvorexant.

Article content: Dr. Kripke provides a very thorough review of available literature, both published and unpublished reports, with regards to various aspects of suvorexant. Existing evidence (or lack thereof) of both efficacy, side-effects, risk/benefit ratio, comparisons studies etc., are clearly presented, and the conclusions drawn from these reports are wellbalanced.

Conclusions: The conclusions are very clearly stated, yet sensible, balanced as well as justified on the basis of the available data regarding suvorexant. I consider this an important contribution that will improve our understanding, and provide a solid scientific foundation useful for both clinicians and researchers alike.

Competing Interests: No competing interests were disclosed.

I confirm that I have read this submission and believe that I have an appropriate level of expertise to confirm that it is of an acceptable scientific standard.

Reviewer Report 05 August 2015

https://doi.org/10.5256/f1000research.7359.r9764

(C) 2015 Siegel J. This is an open access peer review report distributed under the terms of the Creative Commons Attribution License, which permits unrestricted use, distribution, and reproduction in any medium, provided the original work is properly cited. 


\section{Jerome M. Siegel}

Department of Psychiatry and Biobehavioral Sciences, School of Medicine, University of California, Los Angeles, Los Angeles, CA, USA

Kripke presents a thorough analysis of the risks and possible benefits of suvorexant for the treatment of insomnia. Suvorexant is an antagonist for the two receptors for hypocretin (also called orexin), a peptide released by a small group of neurons in the hypothalamus. Soon after the peptide was identified, it was found that $90 \%$ of neurons containing this peptide are lost in human narcolepsy ${ }^{1,2}$. Since one of the main symptoms of narcolepsy is sleepiness, it seemed plausible that a drug blocking hypocretin receptors would cause sleepiness, an effect that might be useful in treating insomnia. Suvorexant is the first such drug to hit the market. Human insomnia is a complaint about inadequate sleep, but is not necessarily correlated with low sleep duration or with decreased lifespan ${ }^{3,4}$.

Current insomnia treatments act on GABA receptors, particularly on the benzodiazepine type of GABA receptor. An obvious problem with manipulation of systemic GABA levels is the very large number of GABA neurons and GABA receptors in the brain. GABA receptors exist not only in regions such as the anterior hypothalamus and adjacent forebrain regions implicated in sleep induction, but throughout the brain. In some regions nearly $90 \%$ of neurons contain $\mathrm{GABA}^{5}$. Benzodiazepine receptors also exist in large numbers in bodily organs including the heart ${ }^{6,7}$, gall bladder, urinary bladder ${ }^{8}$, thyroid, liver ${ }^{9}$, lung, stomach ${ }^{10,11}$, testes ${ }^{11}$, pancreas ${ }^{10}$ and kidneys s $^{10,12}$ and are activated by many commonly used sleeping pills ${ }^{13,14}$. Benzodiazepine receptors are present on red blood cells, on tumors, as well as on cells of the immune system ${ }^{15-19}$. Increased rates of infection have been reported with the use of hypnotics ${ }^{20}$.

In contrast to GABA, there only about 75,000 hypocretin neurons in the human brain $2,21,22$, a tiny fraction of the $75,000,000,000$ neurons estimated to be in the human brain. They are distributed from the most medial portions of the hypothalamus adjacent to the $3^{\text {rd }}$ ventricle, to the far lateral hypothalamus. Although initial reports suggested that there were orexin neurons in the gut, these reports have not been replicated ${ }^{23}$. Hypocretin neurons have widespread projections, directly innervating and activating cortical, subcortical and brainstem neurons ${ }^{24}$.

Some work has suggested potential problems with dual orexin receptor antagonists. Humans who have attempted suicide have reduced levels of hypocretin- 1 in their cerebrospinal fluid ${ }^{25}$. In a study of human patients with electrodes implanted in the amygdala for diagnostic purposes, we found that hypocretin release was maximal during pleasure and was minimal when they reported feeling sad or when they were in pain, despite a high level of arousal ${ }^{26}$. Allowing for species differences, these human data bear considerable resemblance to data on hypocretin neuron activity in animals. In normal mice, we found that hypocretin neurons are maximally active during performance of rewarded behaviors ${ }^{27}$ and that hypocretin knockout mice were strikingly deficient in staying awake to perform rewarded behaviors. Our studies of Fos expression in wild type mice also showed that hypocretin neurons were not activated beyond baseline levels during foot shock, or foot shock avoidance behavior, despite high levels of EEG arousal ${ }^{27}$. We have also reported that hypocretin neuronal activity in rats is suppressed in novel situations eliciting withdrawal, despite maximal levels of EEG activation. In contrast, hypocretin neuron activity is high during grooming and exploration ${ }^{28}$. The animal and human studies indicate that hypocretin cells are not simply related to arousal, but are strongly related to positive emotions. This is consistent with the evidence that human depression and reported difficulties with social interaction in narcolepsy may 
result from the loss of hypocretin function, as would occur with receptor antagonists ${ }^{29-34}$.

These considerations suggest that depression and even suicide might be a risk from the use of orexin receptor antagonists. However, this need not be the case if the drug induces sleep rapidly, and does not persist in the brain. Kripke reviews evidence suggesting that chronic use produces longterm inactivation of hypocretin receptors, highlighting this risk.

\section{References}

1. Peyron C, Faraco J, Rogers W, Ripley B, et al.: A mutation in a case of early onset narcolepsy and a generalized absence of hypocretin peptides in human narcoleptic brains.Nat Med.2000; 6 (9): 991-997 PubMed Abstract | Publisher Full Text

2. Thannickal TC, Moore RY, Nienhuis R, Ramanathan L, et al.: Reduced number of hypocretin neurons in human narcolepsy. Neuron. 2000; 27 (3): 469-474 PubMed Abstract | Publisher Full Text 3. Buysse DJ: Insomnia. JAMA. 2013; 309 (7): 706-716 PubMed Abstract | Free Full Text | Publisher Full Text | Reference Source

4. Kripke DF, Garfinkel L, Wingard DL, Klauber MR, et al.: Mortality associated with sleep duration and insomnia.Arch Gen Psychiatry. 2002; 59 (2): 131-136 PubMed Abstract | Publisher Full Text | Reference Source

5. Zhao C, Eisinger B, Gammie SC: Characterization of GABAergic neurons in the mouse lateral septum: a double fluorescence in situ hybridization and immunohistochemical study using tyramide signal amplification.PLoS One. 2013; 13 (8): e73750 PubMed Abstract | Free Full Text | Publisher Full Text | Reference Source

6. Li J, Xiao J, Liu Y, Zhang G, et al.: Mitochondrial benzodiazepine receptors mediate cardioprotection of estrogen against ischemic ventricular fibrillation.Pharmacol Res.2009; 60 (1): 61-67 PubMed Abstract | Publisher Full Text | Reference Source

7. Brown DA, Aon MA, Akar FG, Liu T, et al.: Effects of 4'-chlorodiazepam on cellular excitationcontraction coupling and ischaemia-reperfusion injury in rabbit heart.Cardiovasc Res.2008; 79 (1): 141-149 PubMed Abstract | Free Full Text | Publisher Full Text | Reference Source

8. Kumar A, Muzik O, Chugani D, Chakraborty P, et al.: PET-derived biodistribution and dosimetry of the benzodiazepine receptor-binding radioligand (11)C-(R)-PK11195 in children and adults.J Nucl Med. 2010; 51 (1): 139-144 PubMed Abstract | Publisher Full Text | Reference Source

9. Luoto $\mathrm{P}$, Laitinen I, Suilamo S, Någren K, et al.: Human dosimetry of carbon-11 labeled N-butan2-yl-1-(2-chlorophenyl)-N-methylisoquinoline-3-carboxamide extrapolated from whole-body distribution kinetics and radiometabolism in rats.Mol Imaging Biol.2010; 12 (4): 435-442 PubMed Abstract | Publisher Full Text | Reference Source

10. Tyagi N, Lominadze D, Gillespie W, Moshal KS, et al.: Differential expression of gammaaminobutyric acid receptor A (GABA(A)) and effects of homocysteine.Clin Chem Lab Med. 2007; 45 (12): 1777-1784 PubMed Abstract | Free Full Text | Publisher Full Text | Reference Source 11. Versijpt J, Dumont F, Thierens $\mathrm{H}$, Jansen $\mathrm{H}$, et al.: Biodistribution and dosimetry of [123I]iodoPK 11195: a potential agent for SPET imaging of the peripheral benzodiazepine receptor.Eur J NuCl Med.2000; 27 (9): 1326-1333 PubMed Abstract | Publisher Full Text

12. Hauet T, Han Z, Wang Y, Hameury F, et al.: Modulation of peripheral-type benzodiazepine receptor levels in a reperfusion injury pig kidney-graft model.Transplantation. 2002; 74 (11): 15071515 PubMed Abstract | Reference Source

13. Veenman L, Gavish M: The peripheral-type benzodiazepine receptor and the cardiovascular system. Implications for drug development.Pharmacol Ther. 2006; 110 (3): 503-524 PubMed 
Abstract | Publisher Full Text | Reference Source

14. Sanna E, Busonero F, Talani G, Carta M, et al.: Comparison of the effects of zaleplon, zolpidem, and triazolam at various GABA(A) receptor subtypes.Eur J Pharmacol.2002; 451 (2): 103-110 PubMed Abstract | Publisher Full Text | Reference Source

15. Miltyk W, Palłka M, Karna E, Jarzabek K, et al.: Antimitotic activity of high affinity ligands for peripheral benzodiazepine receptor (PBR) in some normal and neoplastic cell lines.Adv Med Sci. 2006; 51: 156-159 PubMed Abstract

16. Alam S, Laughton DL, Walding A, Wolstenholme AJ: Human peripheral blood mononuclear cells express GABAA receptor subunits.Mol Immunol.2006; 43 (9): 1432-1442 PubMed Abstract |

Publisher Full Text | Reference Source

17. Costa B, Salvetti A, Rossi L, Spinetti F, et al.: Peripheral benzodiazepine receptor: characterization in human T-lymphoma Jurkat cells.Mol Pharmacol. 2006; 69 (1): 37-44 PubMed Abstract | Publisher Full Text | Reference Source

18. Siegel JM: The neurobiology of sleep.Semin Neurol.2009; 29 (4): 277-296 PubMed Abstract |

Publisher Full Text | Reference Source

19. Lee DH, Kang SK, Lee RH, Ryu JM, et al.: Effects of peripheral benzodiazepine receptor ligands on proliferation and differentiation of human mesenchymal stem cells.J Cell Physiol. 2004; 198 (1): 91-99 PubMed Abstract | Publisher Full Text | Reference Source

20. Joya FL, Kripke DF, Loving RT, Dawson A, et al.: Meta-analyses of hypnotics and infections: eszopiclone, ramelteon, zaleplon, and zolpidem.J Clin Sleep Med. 2009; 5 (4): 377-383 PubMed Abstract | Free Full Text | Reference Source

21. Thannickal TC, Nienhuis R, Siegel JM: Localized loss of hypocretin (orexin) cells in narcolepsy without cataplexy.Sleep. 2009; 32 (8): 993-998 PubMed Abstract | Free Full Text | Reference Source 22. Thannickal TC, Lai YY, Siegel JM: Hypocretin (orexin) cell loss in Parkinson's disease.Brain. 2007; 130 (pt 6): 1586-1595 PubMed Abstract | Publisher Full Text | Reference Source

23. Baumann CR, Clark EL, Pedersen NP, Hecht JL, et al.: Do enteric neurons make hypocretin?. Regul Pept.2008; 147: 1-3 PubMed Abstract | Free Full Text | Publisher Full Text | Reference Source 24. Peyron C, Tighe DK, van den Pol AN, de Lecea L, et al.: Neurons containing hypocretin (orexin) project to multiple neuronal systems.J Neurosci. 1998; 18 (23): 9996-10015 PubMed Abstract I Reference Source

25. Brundin $L, B j o ̈ r k q v i s t ~ M$, Träskman-Bendz $L$, Petersén A: Increased orexin levels in the cerebrospinal fluid the first year after a suicide attempt.J Affect Disord.2009; 113 (1-2): 179-182 PubMed Abstract | Publisher Full Text | Reference Source

26. Blouin AM, Fried I, Wilson CL, Staba RJ, et al.: Human hypocretin and melanin-concentrating hormone levels are linked to emotion and social interaction.Nat Commun.2013; 4: 1547 PubMed Abstract | Free Full Text | Publisher Full Text | Reference Source

27. McGregor R, Wu MF, Barber G, Ramanathan L, et al.: Highly specific role of hypocretin (orexin) neurons: differential activation as a function of diurnal phase, operant reinforcement versus operant avoidance and light level.J Neurosci.2011; 31 (43): 15455-15467 PubMed Abstract | Free Full Text | Publisher Full Text | Reference Source

28. Mileykovskiy BY, Kiyashchenko LI, Siegel JM: Behavioral correlates of activity in identified hypocretin/orexin neurons.Neuron. 2005; 46 (5): 787-798 PubMed Abstract | Publisher Full Text | Reference Source

29. Zamarian L, Högl B, Delazer M, Hingerl K, et al.: Subjective deficits of attention, cognition and depression in patients with narcolepsy.Sleep Med. 2015; 16 (1): 45-51 PubMed Abstract | Publisher Full Text | Reference Source

30. Inocente CO, Gustin MP, Lavault S, Guignard-Perret A, et al.: Depressive feelings in children with narcolepsy.Sleep Med. 2014; 15 (3): 309-314 PubMed Abstract | Publisher Full Text 
31. Ohayon MM: Narcolepsy is complicated by high medical and psychiatric comorbidities: a comparison with the general population.Sleep Med. 2013; 14 (6): 488-492 PubMed Abstract | Publisher Full Text

32. Dimitrova A, Fronczek R, Van der Ploeg J, Scammell T, et al.: Reward-seeking behavior in human narcolepsy.J Clin Sleep Med.2011; 7 (3): 293-300 PubMed Abstract | Free Full Text | Publisher Full Text

33. Mamelak M: Narcolepsy and depression and the neurobiology of gammahydroxybutyrate.Prog Neurobiol.2009; 89 (2): 193-219 PubMed Abstract | Publisher Full Text | Reference Source 34. Szklo-Coxe M, Young T, Finn L, Mignot E: Depression: relationships to sleep paralysis and other sleep disturbances in a community sample.J Sleep Res.2007; 16 (3): 297-312 PubMed Abstract I Free Full Text | Publisher Full Text | Reference Source

Competing Interests: No competing interests were disclosed.

I confirm that I have read this submission and believe that I have an appropriate level of expertise to confirm that it is of an acceptable scientific standard.

The benefits of publishing with F1000Research:

- Your article is published within days, with no editorial bias

- You can publish traditional articles, null/negative results, case reports, data notes and more

- The peer review process is transparent and collaborative

- Your article is indexed in PubMed after passing peer review

- Dedicated customer support at every stage

For pre-submission enquiries, contact research@f1000.com 